\title{
Ciencia, política y práctica: lecciones desde Estados Unidos de América
}

\author{
Science, Policy and Practice - Lessons from America
}

\author{
William B. Hansen*; Linda Dusenbury** \\ *Presidente, President. \\ ** Investigadora, Senior Researcher \\ Tanglewood Research, Inc. \\ Enviar correspondencia a/Correspondence to: \\ William B. Hansen, Ph.D. President, Tanglewood Research. 420-A Gallimore Dairy Road. Greensboro, NC 27409. EE.UU. \\ Telefono, Phone: 1-336-662-0090. billhansen@tanglewood.net
}

\section{RESUMEN}

La experiencia de Estados Unidos con respecto a la prevención del consumo de drogas involucra a tres entidades: los investigadores científicos, los profesionales que trabajan con la juventud y los encargados de las medidas políticas. La sociedad se beneficia del papel complementario de estas entidades. En el pasado, dichas entidades no colaboraban ni aprovechaban el potencial que cada una de ellas podía ofrecer. Los objetivos futuros han de centrarse especialmente en la contribución de los investigadores científicos al desarrollo y comprobación rigurosa de las propuestas programáticas. Los profesionales no sólo han de adoptar programas efectivos y ejecutarlos con fidelidad, sino también deben proporcionar a los científicos la oportunidad de colaborar para lograr que los programas funcionen en ámbitos concretos y con poblaciones específicas. Por último, los encargados de las medidas políticas tienen que apoyar la prevención con financiación y estrategias abiertas a la prevención eficaz e inmunes a los vaivenes políticos. Las entidades de otros países pueden aprender de los treinta años de experiencia en prevención que tiene Estados Unidos.

Palabras clave: política, colaboración, prevención, evaluación, USA.

\begin{abstract}
The experience in the United States regarding drug abuse prevention has involved three entities: scientific researchers, practitioners who work with youth, and policy makers. To the degree that each of these entities play complimentary roles, society benefits. In the past, these three entities have not collaborated or taken advantage of the strengths that each has to offer. Future goals should place an emphasis on scientific researchers contributing to the development and rigorous testing of programmatic approaches. Practitioners not only need to adopt effective programs and implement with fidelity, but also need to provide scientists opportunities to collaborate in order to make programs work for specific settings and populations. Finally, policy makers need to support prevention with funding and policy that is friendly to effective prevention and immune from political whims. Entities outside the United States can learn from the thirty years of experience of prevention experienced in North America.
\end{abstract}

Key words: policy, collaboration, prevention, evaluation, USA.
$\mathbf{E}$ stados Unidos es uno de los países con mayor índice de consumo de drogas. En las últimas tres décadas se han registrado incrementos y descensos esporádicos en las tasas de consumo de drogas entre adolescentes $y$, como respuesta, han surgido tres entidades de trabajo distintas: la ciencia, la política y la práctica. Estas entidades no siempre han colaborado mutuamente. Sin embargo, cada vez resulta más evidente la necesidad de una acción cooperativa para que la sociedad solucione este problema
$\mathbf{T}$ The United States is among the nations with the highest drug use rates. The past three decades have witnessed sporadic increases and decreases in drug use rates among adolescents and, in response, the emergence of three separate contributing entities: science, policy and practice. These entities have not always worked well together. However, it is becoming clear that cooperative action is needed in order for society to come to an ultimate solution to this problem. The solution to the drug use 
de forma definitiva. La solución del problema del consumo de drogas es como un banco con tres patas: si la política, la práctica y la ciencia están desligadas, la sociedad se ve perjudicada. Cuando los elementos se desequilibran, cuando falta una pata o es más corta que las otras, la sociedad sufre la desventaja.

Este artículo es una reflexión acerca de la experiencia de las tres últimas décadas en Estados Unidos, describe la contribución de cada una de las entidades y los cambios y modestos éxitos que se han conseguido. Además, se propone una estrategia de futuro relevante para todos los países.

\section{CIENCIA}

Antes de 1975 prácticamente no había investigación sobre la prevención del consumo de drogas. El Instituto Nacional del Consumo de Drogas (NIDA) y el Instituto Nacional del Consumo de Alcohol y el Alcoholismo se crearon en 1974 (NIH, 2007). Al año siguiente se inició la encuesta anual de estudiantes de últimos cursos de enseñanza secundaria (el proyecto Observación del Futuro - Monitoring the Future-l, que proporcionó tasas anuales de incidencia y prevalencia de una amplia variedad de sustancias (Johnston, O’Malley, Bachman y Schulenberg, 2007). Esta investigación fue crucial para comprender la epidemiología del consumo de drogas entre estudiantes y permitió la observación longitudinal de tendencias de consumo de drogas en Estados Unidos durante treinta años.

La siguiente prioridad de la investigación fue comprender la etiología del consumo de drogas entre los jóvenes. Numerosos investigadores recibieron subvenciones iniciales del NIDA y el NIAAA. Las subvenciones se otorgaron según criterios competitivos y de revisión colegiada. La mayoría de los proyectos de investigación etiológica se basaban en nuevas teorías de investigadores de las disciplinas afines: psicología social, sociología, psicología clínica, psicología del desarrollo, economía y salud pública, y reflejaban una variada gama de enfoques del problema. La investigación sobre la etiología trataba casi siempre de responder, a través de estudios longitudinales de jóvenes al llegar a la edad adulta, las correlaciones psicológicas, sociológicas y ambientales que predisponían al consumo de drogas.

A finales de los años setenta el NIDA y el NIAAA subvencionaron estudios de intervención, con un énfasis acentuado en los enfoques escolar y comunitario que florecieron en las décadas de los ochenta y los noventa. La investigación de las intervenciones, como la investigación etiológica, se basaba fundamentalmente en la disciplina educativa de los inves- problem is like a stool with three legs. When policy, practice and science are to disconnected, little or no benefit to society can be expected. Even when the elements are out of balance, as when one leg is missing or shorter than the others, society misses the full benefit.

This paper reflects upon the past three decades of experience in the United States, describing the contribution of each entity and the challenges and modest successes that have been achieved. A strategy for the future that is relevant to all nations is proposed.

\section{SCIENCE}

Research in drug abuse prevention was practically non-existent prior to 1975. The National Institute on Drug Abuse (NIDA) and the National Institute on Alcohol Abuse and Alcoholism were established in 1974 (NIH, 2007). The next year, an annual survey of high school seniors (the Monitoring the Future project) was funded, which began to provide annual incidence and prevalence rates of a wide variety of substances (Johnston, O'Malley, Bachman, \& Schulenberg, 2007). This research was crucial to understanding the epidemiology of drug use among students and has allowed trends in drug use to be monitored longitudinally in the United States for 30 years.

Understanding the etiology of drug use among young people became the next priority for research. Numerous researchers were funded with grants from NIDA and NIAAA. Research funding was awarded on a competitive and peer reviewed basis. Most etiologic research projects were based on testing theories from researchers' host disciplines: social psychology, sociology, clinical psychology, developmental psychology, economics, and public health and reflected a diverse set of approaches to the problem. Most often, research in etiology attempted to answer, through longitudinal studies of youth as they matured, what psychological, sociological, and environmental correlates predicted drug use.

Intervention studies were also funded by NIDA and NIAAA beginning in the late 1970s, with expanded emphasis on school and community approaches flourishing in the 1980s and 1990s. Intervention research, like etiologic research, was often based on the educational discipline of the researchers who 
tigadores que pedían subvenciones. La investigación sobre la prevención del consumo de drogas formulaba la pregunta: "¿Las estrategias de prevención desarrolladas reducirán de forma efectiva la incidencia del consumo de drogas?» Durante los años ochenta y noventa, el eje de la investigación sobre la prevención del consumo de drogas cambió ligeramente, al menos en Estados Unidos. En este período la investigación se centró en identificar si las intervenciones que contenían determinados elementos (por ejemplo, entrenamiento en estrategias de resistencia, educación normativa, entrenamiento en habilidades personales y sociales extensas) prevenían la aparición del consumo de alcohol, tabaco, marihuana, inhalantes y otras variedades de drogas (Hansen, 1992; Hawkins, Catalano y Miller, 1992). Posteriormente, la pregunta formulada por los investigadores evolucionó de: "¿Funciona la prevención?» a "¿Cómo se pueden conseguir programas más eficaces?» Los objetivos de la investigación solían limitarse a establecer la eficacia en determinadas condiciones. El prototipo de investigación estándar consistía en una prueba de control aleatorio. Con el cambio de milenio surgieron las pruebas científicas que apoyaban prácticas prometedoras basadas en la investigación (Tobler y Stratton, 1997). Se creó asimismo un extenso cuerpo investigador. Sin embargo, aún deben sintetizarse diversas teorías sobre la forma de prevenir el consumo de drogas entre adolescentes (Hansen, Dusenbury, Bishop y Derzon, 2006).

Ha descendido el número de proyectos de investigación subvencionados por el NIDA y el NIAAA en los últimos años. Por ejemplo, en 2006 había once proyectos nuevos de prevención registrados en la base de datos del $\mathrm{NIH}(\mathrm{NIH}, 2007 \mathrm{c})$, mientras que en el 2000 los proyectos eran veinte. Hasta fechas recientes no se ha subvencionado la investigación que examina cómo se adoptan y adaptan programas de prevención aislados.

\section{POLÍTICA}

Los países europeos han impuesto políticas propias, que van desde una postura de no tolerancia a políticas centradas esencialmente en la reducción de daños. En las tres últimas décadas, los objetivos de la política nacional americana tendieron a eliminar el consumo de drogas y emprendieron una "guerra contra las drogas».

Las políticas americanas sobre drogas empezaron con la Ley Harrison, aprobada en 1914. Esta ley gravaba la venta de heroína, opiáceos y cocaína con fines no medicinales (a razón de mil dólares por transacción), con lo que en realidad se convertía en ile- sought funding. Research in drug abuse prevention asked the question, "Can prevention strategies be developed that are effective at reducing incidence of drug use?" During the 1980s and 1990s, the focus on drug abuse prevention research shifted slightly, at least in the United States. Research during this period was designed to identify whether interventions containing certain elements (e.g., resistance skills training, normative education, broader personal and social skills training) could be demonstrated to deter the onset of alcohol, tobacco, marijuana, inhalants, and other forms of drug use (Hansen, 1992; Hawkins, Catalano \& Miller, 1992). More recently, the question researchers ask has evolved from "Can prevention work?" to "What can make programs more efficacious ?" Research goals were often limited to establishing efficacy under defined conditions. The standard research design was a randomized control trial. By the millennium, scientific evidence supporting promising researchbased practices was emerging (Tobler \& Stratton, 1997). A large body of research emerged. However, yet to be synthesized are theories of how to prevent drug use among adolescence (Hansen, Dusenbury, Bishop, \& Derzon, 2006).

There has been a decrease in the number of research projects funded by NIDA and NIAAA in the recent past. For example, in 2006, there were 11 new prevention projects listed in the $\mathrm{NIH}$ database (NIH, 2007c) where there were 20 projects in 2000. Research has only recently been funded to examine how prevention programs are adopted and adapted when they are disseminated.

\section{POLICY}

European countries have had policies that have been distinctive and have ranged from a no tolerance stance to policies that focused primarily on harm reduction. During the last three decades, American national policy goals were to eliminate drug use and abuse and a "war on drugs" was pursued.

America's policies about drug use started with the Harrison Act, passed in 1914. This act taxed the sale of heroin, opiates, and cocaine for nonmedicinal purposes - at \$1,000 per transaction - essentially making the use of these substances 
gal el consumo de dichas sustancias. La regulación del consumo de alcohol comenzó en la década de los veinte con la aprobación de la enmienda decimoctava a la Constitución, que declaraba ilegal en todo el territorio nacional la fabricación, venta y transporte de bebidas alcohólicas. La enmienda veintiuna, aprobada en 1933, revocó la enmienda de prohibición y entregó el control sobre el alcohol a los estados. Antes de 1937 veintisiete estados habían aprobado leyes que prohibían la marihuana. El gobierno federal creó en los años treinta una agencia, la Oficina Federal de Narcóticos, a la que se encomendó la labor de interdicción. Este organismo se convirtió en Agencia para el Control de Drogas (DEA) durante la administración Nixon en 1971. Por último, en 1978 se creó la Oficina de Política Nacional para el Control de Drogas. El objetivo esencial de casi todas las políticas estadounidenses era el control del alcohol y del consumo de drogas por medio de la interdicción y de la imposición de la ley.

Los trabajos para la prevención de las drogas recibieron financiación federal por primera vez en 1985, cuando se aprobó la Ley por las Escuelas y Comunidades sin Drogas. Esta ley aportó fondos a las escuelas. La financiación de la prevención se hizo sin restricciones en principio: no se exigía a las agencias locales que adoptasen programas de efectos demostrados ni debían avalar su efectividad.

Aparte de la financiación basada en la escuela, la Ley por las Escuelas y Comunidades sin Drogas creó también una Oficina para la Prevención del Consumo de Sustancias (OSAP), que posteriormente pasó a denominarse Centro para la Prevención del Consumo de Sustancias (CSAP), encargado de proporcionar fondos para proyectos comunitarios especiales, como las coaliciones comunitarias. Finalmente, se creó un programa llamado Donación de Incentivos Estatales (SIG), con fondos federales distribuidos a través de donaciones que se conceden a los estados, que los administran siguiendo pautas federales.

En los años ochenta las subvenciones para la prevención sirvió sobre todo para dar una imagen pública positiva a los políticos. Sin embargo, cuando el consumo de drogas aumentó a principios de los noventa, como denunció el proyecto Observación del Futuro, las agencias federales implantaron políticas más avanzadas para atender los problemas emergentes. A partir de entonces, las políticas exigieron pruebas de efectividad a los programas. Los programas basados en la investigación recibieron la sanción oficial mediante la inclusión en listas como el Registro Nacional de Prácticas y Programas Efectivos (National Registry of Effective Programs and Practices, NREPP). No obstante, el financiamiento y el apoyo de la prevención siguen teniendo problemas. La proporción de presupuesto federal otorgado a la prevención illegal. The regulation of alcohol use started in the 1920 s with the passage of the $18^{\text {th }}$ amendment to the Constitution that made it illegal nationwide to manufacture, sell, or transport alcoholic beverages. The $21^{\text {st }}$ Amendment, passed in 1933, repealed the prohibition amendment and passed control of alcohol to states. Prior to 1937, 27 states had passed marijuana prohibition laws. The federal government established an agency, the Federal Bureau of Narcotics, in the 1930s, which was given the task of interdiction. This agency was transformed into the Drug Enforcement Agency (DEA) during the Nixon administration in 1971. The Office of National Drug Control Policy was finally established in 1978. The primary objective of nearly all policy in the United States was the control alcohol and drug use through interdiction and law enforcement.

Drug prevention efforts first received federal funding in 1985 with the passage of the Drug-Free Schools and Communities Act. This act provided funding to schools. Prevention funding initially came with no strings - local agencies did not need to adopt programs with proven effects and they did not need to demonstrate effectiveness.

In addition to school based funding, the DrugFree Schools and Communities Act also established an Office for Substance Abuse Prevention (OSAP), later changed to the Center for Substance Abuse Prevention (CSAP) that was charged with providing funding for special community projects, such as funding community coalitions. Eventually, a program known as the State Incentive Grant (SIG) program was funded, with federal funds distributed by means of grants given to states, allowing states to administer funding under federal guidelines.

During the 1980s, prevention funding primarily served to promote positive public relations for politicians. However, when drug use began to increase during the early 1990s as reported by the Monitoring the Future project, federal agencies began to institute more enlightened policies designed to address emerging problems. Policies now dictate that programs should have evidence of effectiveness. Research-based programs are now officially sanctioned on such lists as the National Registry of Effective Programs and Practices (NREPP). Nonetheless, funding and support for prevention continues to struggle. The proportion of the federal budget given to prevention when compared to the interdiction budget is extremely small. The budget for Safe and Drug-Free Schools 
es extremadamente pequeño si se compara con el presupuesto de interdicción. El presupuesto para las Comunidades y Escuelas Seguras y sin Drogas propuesto por la administración reduciría dicha financiación a la mitad.

\section{PRÁCTICA}

Los profesionales, las personas que realizan servicios de prevención del consumo de drogas y de alcohol entre la juventud se dividen fundamentalmente en tres grupos: activistas, proveedores de servicios profesionales centrados en la comunidad y profesores. Como cada grupo tiene prácticas diferentes, las describiremos.

Los activistas constituyen un grupo generalmente afectado por las consecuencias del consumo de drogas y de alcohol, bien de forma directa, a través de un familiar o de un compañero de trabajo. Conocen los horrores de la adicción y suelen guiarse por su propia dedicación y su experiencia personal a la hora de abordar su trabajo. No es raro que sean muy carismáticos y con enfoques muy emocionales. Mientras los investigadores albergan la esperanza de que la ciencia oriente la práctica, los activistas no son partidarios de confiar en la ciencia para hallar soluciones, sobre todo porque los científicos se muestran muy reticentes a la hora de extraer conclusiones sobre la efectividad debido a su formación investigadora.

La prevención suele ser obra de los profesores habituales. Chris Ringwalt y sus colegas (Ringwalt, Ennett, Johnson, Rohrbach, Simons-Rudolph, Vincus y Thorne, 2003) y Denise Hallfors y su colega (Hallfors y Godette, 2002) estudiaron las escuelas en el cambio de milenio y encontraron un número considerable que había adoptado programas de educación sobre drogas, muchos de ellos basados en la investigación. Por desgracia, como indican los datos presentados por estos investigadores, la adhesión de este grupo a los protocolos de los programas varía notablemente. Muchos profesores modifican los programas, omitiendo gran parte de lo que los programas les exigen.

Los proveedores de servicios a la comunidad son profesionales de reciente aparición. Originariamente, el mayor grupo de proveedores eran empleados del DARE (Programa Educativo para la Resistencia al Consumo de Drogas), hombres y mujeres que impartían un programa a estudiantes de los últimos cursos de la escuela elemental y que se amplió gradualmente a estudiantes de enseñanza secundaria. Aunque el DARE se impartía con fidelidad, ha sido objeto de amplias críticas que lo tachan de programa ineficaz (Ennett, Tobler, Ringwalt y Flewelling, 1994), and Communities currently proposed by the administration would reduce funding by half.

\section{PRACTICE}

Practitioners, the people who actually provide drug and alcohol prevention services to youth primarily consist of three groups: activists, community-based professional service providers, and teachers. Because the practices of each group are distinct, each will be described.

Activists are a group who have typically been touched by the consequences of drug and alcohol abuse - either themselves directly or because of a family member or co-worker. They know the horrors of addiction and have often relied on their own dedication and personal experience to guide their practice. It is not unusual for them to be highly charismatic and highly emotional in their approach. While researchers offered hope that science could guide practice, activists had no inclination to wait for science to find solutions, particularly when scientists were so reluctant because of their research training to draw conclusions about what was effective.

Prevention is often provided by regular classroom teachers. Chris Ringwalt and his colleagues (Ringwalt, Ennett, Johnson, Rohrbach, SimonsRudolph, Vincus, \& Thorne, 2003) and Denise Hallfors and her colleague (Hallfors \& Godette, 2002) examined schools around the turn of the millennium and found a sizable number had adopted drug education programs, many researchbased. Unfortunately, as data presented by these researchers suggest, adherence to program protocols by this group varies considerably. Many teachers modify programs, omitting much of what programs ask them to do.

Community-based service providers are a newly emerging breed of practitioner. Originally, the largest group of providers were DARE officers, men and women who delivered a program to students in their last year of elementary school, gradually expanded to included middle school students as well. While generally delivered with good fidelity, DARE has come under extensive attack for being an ineffective program (Ennett, Tobler, Ringwalt, \& Flewelling, 1994) and a number of DARE programs have been abandoned. More recently, local funding from SIG 
y se ha abandonado en muchos casos. En época más reciente, la financiación local de las subvenciones del SIG ha permitido que las agencias contraten a especialistas en prevención que trabajan con los jóvenes en comunidades y escuelas e imparten programas. Muchas veces, estos proveedores poseen formación especializada en los programas que ofrecen.

A menudo los profesionales carecen de la formación adecuada para entender los objetivos y métodos de los programas basados en la investigación. La fidelidad se asocia a los resultados positivos. En la evaluación del Proyecto STAR los profesores omitieron por término medio un $25 \%$ del programa (Pentz, Trebow, Hansen, MacKinnon, Dwyer, Johnson, Flay, Daniela y Cormack, 1990). A mayor exposición del programa, mayor reducción en el consumo de alcohol, tabaco y marihuana. La proporción del programa impartido a los estudiantes provoca mayor varianza que la participación en un tratamiento experimental. Tortu y Botvin (1989) indican que los profesores que impartían Preparación en Habilidades de la Vida daban por término medio el $65 \%$ del curriculum, con una variación que oscila entre el $44 \%$ y el $83 \%$. En este estudio se observa que las clases que recibieron el programa con fidelidad (al menos el 60\% del mismo) registraban un consumo mucho menor de cigarrillos y de marihuana (Botvin et al., 1990). Una evaluación de una versión dispersa del Proyecto SMART (Rohrbach, Graham y Hansen, 1993) descubrió que más de uno, de cada cinco profesores adiestrados para ejecutar el programa, no lo impartió en el año posterior a su adiestramiento. Y sólo uno de cada cuatro profesores ofreció el programa al año siguiente.

\section{EL FUTURO DE LA PREVENCIÓN}

En Estados Unidos se tiende al desarrollo de una ciencia de la prevención rigurosa y a la adopción de prácticas comprobadas científicamente por los proveedores de servicios de prevención. Sin embargo, es evidente que aún no hemos alcanzado nuestro potencial pleno. A continuación se ofrece una crítica de lo que se está por hacer.

La investigación actual se centra cada vez más en ver cómo funcionan en la práctica los programas de prevención cuando se ejecutan en el mundo real, sin una adhesión estricta a calendarios de ejecución y formatos dictados por los estudios científicos. Los investigadores empiezan a pensar en las modificaciones que deben hacerse en programas pensados para responder a preguntas científicas de forma que se acomoden a las necesidades y al trabajo de los proveedores de servicios locales. Los programas basados en la investigación no se desarrollaron pen- grants has allowed agencies to hire prevention specialists who work with youth in community and school settings to provide programs. In many cases, these providers seek specialized training in the programs they deliver.

Practitioners are infrequently not fully trained to understand the goals and methods of researchbased programs. Fidelity is associated with positive program outcomes. In the evaluation of Project STAR, teachers omitted an average of $25 \%$ of the program (Pentz Trebow, Hansen, MacKinnon, Dwyer, Johnson, Flay, Daniels, \& Cormack, 1990). Increased exposure to the program predicted reduced alcohol, cigarette, and marijuana use. The amount of exposure students received of the program accounted for more variance than did assignment to the experimental treatment condition. Tortu and Botvin (1989) report that teachers delivering Life Skills Training on average implemented $65 \%$ of the curriculum with teachers varying between $44 \%$ and $83 \%$. In this study, classes that received the program with high fidelity - at least $60 \%$ of the program - had significantly less onset of cigarette smoking and marijuana use (Botvin, et al., 1990). An evaluation of a disseminated version of Project SMART (Rohrbach, Graham \& Hansen, 1993) found that more than one in five teachers who had been trained to implement the program simply did not do so during the year following training. Only one of four teachers implemented the program the next year.

\section{THE FUTURE OF PREVENTION}

There is an emergent trend in the United States toward the development of a rigorous prevention science and the adoption of scientifically validated practices by prevention providers. However, it is clear that we have not yet achieved our full potential. The following is a critique of what has yet to be accomplished.

Research today is focusing increasingly on understanding how prevention programs work in practice, when implemented under real world conditions, and without strict adherence to implementation schedules and formats dictated by research studies. Researchers are just now beginning to ask questions about how programs designed to answer scientific questions can and need to be altered to meet the needs and practices of local service providers. Research-based programs were 
sando en la adaptación. ¿Cómo pueden colaborar los investigadores y los profesionales para conseguir que los programas de prevención funcionen en diferentes ámbitos y con poblaciones distintas? Existen nuevas tecnologías de trabajo que aún no se han incorporado como métodos potenciales. También hay nuevos hallazgos etiológicos — por ejemplo, sobre el desarroIlo cerebral-, que han de incorporarse a los programas con el fin de comprobar su efectividad.

La investigación de la puesta en práctica exige nuevos métodos. Los grupos de control —un rasgo fundamental de los métodos de investigación que se lleva a cabo cuando se desarrollan los programascasi nunca están disponibles o no quieren participar.

Los investigadores se han dedicado a la investigación de campo y han prestado poca atención al desarrollo de una teoría de la prevención concisa y con fundamentos empíricos. Suele haber un desequilibrio entre lo que los programas definen como teoría subyacente y su construcción (Hansen, Dusenbury, Baker y Derzon, 2006). La construcción y el refinamiento teóricos son necesarios para el progreso de la ciencia.

Los programas han de ejecutarse con fidelidad, aunque las políticas sobre formación y control aún no se hayan definido. En este punto, nuestra observación de la relación entre estos factores y la fidelidad se limita a impresiones no avaladas por la investigación sistemática.

Por último, aunque tal vez sea lo más importante en la presente situación, la política no acaba de funcionar plenamente. La historia de la política en Estados Unidos ha dado prioridad a la interdicción, a pesar del escaso éxito de la misma a la hora de reducir el perjuicio nacional causado por el alcohol y las drogas. La financiación de la prevención siempre ha resultado insuficiente y sigue siendo un tema muy manido. Sin mayores aportaciones económicas a la investigación y la práctica, los logros de las últimas tres décadas podrían perderse. Las decisiones políticas casi nunca tienen en cuenta la ciencia. El tema de la prevención sólo mejorará con financiación estable.

Hemos escrito este artículo sin conocer la experiencia de otros países, hasta qué punto la ciencia, la política y la práctica colaboran para crear una juventud sin adicciones y sin los perjuicios causados por el consumo de alcohol y drogas. En cualquier caso, creemos que cada dominio debe trabajar con los demás en bien del progreso y para que se desarrollen y ejecuten estrategias de prevención efectivas. not developed with adaptation in mind. How can researchers and practitioners work together to make prevention programs work in diverse settings with diverse populations? There are new technologies for delivery that have not yet been incorporated as potential methods of delivery. There are also emergent new etiologic findings - for example about brain development - which eventually need to be integrated into programs and tested for effectiveness.

Research on implementation requires new methods. The use of control groups - a standard feature of research methods conducted when programs were being developed - are rarely available or willing to participate.

Researchers have been engrossed in field research and have paid little attention to developing a concise and empirically supported theory of prevention. There is often a mismatch between what programs claim as their underlying theory and their construction (Hansen, Dusenbury, Baker, \& Derzon, 2006). For science to progress further, theory construction and refinement will be required.

Program should be implemented with fidelity as intended, although policies about training and monitoring are not yet defined. At this point, our understanding about the relationship between these factors and fidelity amounts to impressions uninformed by systematic research.

Finally, and perhaps most important in the current situation, policy is not yet fully functional. The history of policy in the United States has consistently given priority to interdiction, despite little apparent success of this approach as a means of reducing the national harm caused by alcohol and drugs. Funding for prevention has always been insufficient and continues to be a political football. Without increased funding for research and practice, gains from the last three decades may ultimately be lost. Policy decisions are rarely informed by science. Only when stable funding is provided will the state of the art in prevention improve.

We write this editorial not knowing about the experience of other nations- the degree to which science, policy, and practice come together to create youth who are free from addiction and the harm caused by alcohol and drug use and abuse. In any case, we conclude that each domain must work together for progress to be made and for effective prevention strategies to be developed and delivered. 


\section{REFERENCIAS/ REFERENCES}

Botvin, G.J., Baker, E., Dusenbury, L., Tortu, S. et al. (1990) Preventing adolescent drug abuse through a multimodal cognitive-behavioral approach: Results of a 3-year study. Journal of Consulting and Clinical Psychology, 58, 437-446.

Hallfors D., \& Godette D. (2002). Principles of effectiveness improve prevention practice? Early findings from a diffusion study. Health Education Research, 17(4), 461-470.

Hansen, W.B. (1992), "School based substance abuse prevention: a review of the state-of-the-art in curriculum, 1980-1990", Health Education Research, Vol. 7, pp. 403-30.

Hansen WB, Dusenbury L, Bishop D, \& Derzon JH. (2006). Substance abuse prevention program content: Systematizing the classification of what programs target for change. Health Education Research. doi:10.1093

Hawkins JD, Catalano RF, \& Miller JY. (1992). Risk and protective factors for alcohol and other drug problems in adolescence and early adulthood: Implications for substance abuse prevention. Psychological Bulletin, 112(1); 64-105.

Ennett S.T., Tobler N.S., Ringwalt C.L., Flewelling R.L. (1995). How effective is drug abuse resistance education? A meta-analysis of Project DARE outcome evaluations. American Journal of Public Health, 85 (6) 873-874

Johnston, L. D., O'Malley, P. M., Bachman, J. G., \& Schulenberg, J. E. (2006). Monitoring the Future national survey results on drug use, 1975-2005. Volume I: Secondary school students (NIH Publication
No. 06-5883). Bethesda, MD: National Institute on Drug Abuse, 684 pp.

NIH (2007c). CRISP: ERA Commons Computer Retrieval of Information on Scientific Projects http://crisp.cit.nih.gov/ $\mathrm{NIH}$ (2007a). National Institute on Drug Abuse: Important Events in NIDA History. Found at http://www.nih.gov/about/ almanac/archive/1999/organization/nida/history.html

NIH (2007b). National Institute on Alcohol Abuse and Alcoholism: Important Events in NIAAA History. Found at http://www.nih.gov/about/almanac/archive/1999/ organization/niaaa/history.html.

Pentz, M.A,, Trebow, E.A., Hansen, W.B., MacKinnon, D.B., Dwyer, J.H., Johnson, C.A., Flay, B.F., Daniels, S., and Cormack, C.C. (1990). Effects of program implementation on adolescent drug use behavior: The Midwestern Prevention Project (MPP). Evaluation Review, 14, 264-289.

Ringwalt CL, Ennett ST, Johnson R, Rohrbach LA, SimonsRudolph AP, Vincus AA, \& Thorne, J. (2003). Factors associated with fidelity to substance use prevention curriculum guides. Health Education and Behavior, 30, 375-391.

Rohrbach LA, Graham JW, Hansen WB. (1993). Diffusion of a school-based substance abuse prevention program: Predictors of program implementation. Preventive Medicine, 22, 237-260.

Tobler NS. \& Stratton H. (1997). Effectiveness of schoolbased drug prevention programs: A meta-analysis of the research. Journal of Primary Prevention, 18 (1), 71-128.

Tortu, S., \& Botvin, G., (1989). School-based smoking prevention: The teacher training process. Preventive Medicine, 18, 280-289. 